\title{
High Survival Rate of Bovine Oocytes Matured In Vitro Following Vitrification
}

\author{
Ri-Cheng CHIAN ${ }^{1,4)}$, Masashige KUWAYAMA ${ }^{2)}$, Leonard TAN1), Justin TAN ${ }^{1}$, \\ Osamu $\mathrm{KATO}^{2)}$ and Takashi NAGAI ${ }^{3)}$
}

1) Division of Reproductive Biology, Department of Obstetrics and Gynecology, McGill University, Montreal, Canada H3A 1A1, ${ }^{2)}$ Kato Ladies Clinic, Tokyo, ${ }^{3)}$ National Institute of Livestock and Grassland Sciences, Tsukuba, Japan, ${ }^{4}$ Women's Pavilion F3-46, Royal Victoria Hospital, 687 Pine Avenue West, Montreal, Canada H3A 1A1

\begin{abstract}
Improving pregnancy rates associated with the use of cryopreserved human oocytes would be an important advance in human assisted reproductive technology (ART). Vitrification allows glasslike solidification of a solution without ice crystal formation in the living cells. We have attempted to improve the survival rates of oocytes by a vitrification technique using bovine models. In vitro matured oocytes with or without cumulus cells were vitrified with either $15.0 \%(\mathrm{v} / \mathrm{v})$ ethylene glycol $(\mathrm{EG})+15 \%(\mathrm{v} / \mathrm{v})$ dimethylsulfoxide (DMSO) $+0.5 \mathrm{M}$ sucrose or $15 \%(\mathrm{v} / \mathrm{v}) \mathrm{EG}+15 \%(\mathrm{v} / \mathrm{v}) 1,2-$ propanediol $(\mathrm{PROH})+0.5 \mathrm{M}$ sucrose, using 'Cryotop' or 'thin plastic sticker', respectively. The oocyte survival rates after vitrifying-warming, and the capacity for fertilization and embryonic development were examined in vitro. The rate of embryonic development to blastocyst was significantly higher $(\mathrm{P}<0.05)$ in the oocytes vitrified with $15 \%(\mathrm{v} / \mathrm{v}) \mathrm{EG}+15 \%(\mathrm{v} / \mathrm{v}) \mathrm{PROH}+0.5 \mathrm{M}$ sucrose than in the oocytes vitrified with $15 \%(\mathrm{v} / \mathrm{v}) \mathrm{EG}+15 \%(\mathrm{v} / \mathrm{v}) \mathrm{DMSO}+0.5 \mathrm{M}$ sucrose $(7.4 \% \pm 4.1 \mathrm{vs} .1 .7 \% \pm 3.0$, respectively). Oocytes vitrified without cumulus cells had a higher survival rate after thawing and a superior embryonic developmental capacity compared with oocytes vitrified with cumulus cells. Prolonged pre-incubation time after thawing adversely affected the rates of embryonic cleavage and development. These results indicate that in vitro matured bovine oocytes can be vitrified successfully with the mixture of the cryoprotectants, $\mathrm{EG}+\mathrm{PROH}$, the absence of cumulus cells for vitrification does not affect oocyte survival rate after warming, and vitrified and warmed oocytes do not require pre-incubation before in vitro fertilization.
\end{abstract}

Key words: Bovine, Oocyte, Vitrification, Cryotop, Embryo

(J. Reprod. Dev. 50: 685-696, 2004)

C ryopreservation of human oocytes is a powerful tool in assisted reproductive technology (ART). It would be a useful treatment option for women who are at risk of losing their ovarian function because of pelvic diseases, surgery or radio/ chemotherapy and could also avoid some of the moral and ethical problems posed by embryo

Accepted for publication: September 22, 2004

Correspondence: R-C.Chian

(e-mail:ri-cheng.chian@muhc.mcgill.ca) freezing. Although several pregnancies and live births following freezing and thawing of human oocytes have been reported [1-13], human oocyte freezing as a technology is still considered to be at an early developmental stage. Improving pregnancy rates associated with the use of cryopreserved human oocytes would be a major advance in human ART.

Although live young have been produced from cryopreserved oocytes in the mouse using a slow 
freezing [14], the method has met very limited success in other species $[15,16]$ including humans [1-9]. Mammalian oocytes have proven to be more difficult to cryopreserve than cleavage-stage embryos [17], and the efficiency of oocyte cryopreservation in most species, except for the mouse, is still very low (for a review, see [18]). An important problem limiting oocyte cryopreservation is the survival rate after freezingthawing. Porcu et al. [9] have reported a 54.1\% survival rate of human oocytes after slow freezing (out of a sample size of 1,502 oocytes), but recently Fabbri et al. [19] have reported a $82 \%$ survival rate $(183 / 224)$. Therefore, oocyte survival and pregnancy rates by slow freezing remain to be improved. Recently pregnancies and live births after cryopreservation of human oocytes using vitrification were reported [10,11], indicating that vitrification is a promising novel technique in ART [20].

Vitrification is a process in which glasslike solidification of a solution occurs without the formation of ice crystal inside living cells within the solution during cooling and warming. Increasing the freezing speed can induce vitrification in embryos [21]. The freezing speed can be increased enough by plunging into liquid nitrogen directly, using an electron microscopy grid [11, 22-27], an open pulled straw (OPS) [10, 16], a cryoloop [2831], or a cryotop [32]. In addition, most vitrification protocols use very high concentrations of cryoprotectants that rapidly dehydrate the cells or embryos [33]. Therefore, it indicates that there is a strong correlation between concentration of cryoprotectant and cooling-warming rates during the vitrification process. Although dimethylsuphoxide (DMSO) was initially used as a cryoprotectant for human embryos [34], there has been increasing tendency to use 1,2-propandiol (propylene glycol; PROH) instead since DMSO may cause spindle polymerization with increased risk for polyploidy [35]. Furthermore, ethylene glycol (EG) has been used widely for the vitrification of human oocytes [10,25] and embryos $[26,27,30,31,36-38]$ due to its low molecular weight, high permeation ability and low toxicity. Moreover, it has been reported that cryoprotectant mixtures may have some advantages over solutions containing only one permeable cryoprotectant [16]. Mukaida et al. [31] reported that $80.4 \%$ of blastocysts survived after vitrification using a mixture of $15 \%(\mathrm{v} / \mathrm{v})$ of EG and DMSO. However, it remains unclear if the mixture of EG and DMSO could be replaced by a mixture of EG and $\mathrm{PROH}$ for oocyte vitrification.

Another issue that may affect oocyte survival rates after freezing-thawing is whether there are cumulus cells around the oocytes prior to freezing. Whittingham [14] found that survival rate of mouse oocytes after freezing-thawing is not different between oocytes with or without cumulus cells prior to freezing. Although beneficial effects of cumulus cells on oocyte survival after freezingthawing have been reported by some investigators [39-41], a recent study suggested that there is no difference in post-thawing cryosurvival rates for human oocytes cryopreserved with or without cumulus cells when a slow freezing method is used [19]. Therefore, the effect of cumulus cells on oocyte cryosurvival following a slow freezing remains to be clarified. With regard to vitrification, there is a paucity of information on the involvement of cumulus cells in oocyte cryosurvival following vitrification.

Incubation of frozen-thawed oocytes before insemination seems to allow recovery from the injury associated with the slow freezing procedure $[42,43]$. Pre-incubation of post-thawed bovine oocytes improves the fertilizability and embryonic developmental capacity [44, 45]. It has been reported that frozen-thawed bovine oocytes need to be pre-incubated for $2 \mathrm{~h}$ before insemination in order to recover from abnormalities of the chromosome and meiotic spindle [41]. It is, however, unclear whether pre-incubation is necessary for vitrified oocytes before insemination.

In our laboratory, recently we have established serum-free system of bovine oocytes maturation in vitro and embryonic development in vitro. This allows us to use the system studying of oocyte vitrification in order to develop a technique apply for human ART in the near future, because our preliminary study indicated that bovine in vitro matured oocytes are more suitable model for human oocytes to develop new culture medium and freezing method than mouse oocytes (unpublished data).

The objectives of the present study, using a bovine model, were to determine the effect of (1) a mixture of EG and PROH as cryoprotectant, (2) existence of cumulus cells prior to vitrification, and (3) pre-incubation time of oocytes after thawing, on 
oocyte survival, fertilizability and subsequent early embryonic development, when oocytes were vitrified using Cryotop or a plastic sticker. All of the above was to optimize the survival rate for a subsequent clinical trial on the vitrification of human oocytes.

\section{Materials and Methods}

\section{Collection of immature oocytes}

Ovaries from heifers or cows were collected from a local abattoir. The ovaries were removed within 30 min of slaughter and transported to the laboratory at $35 \mathrm{C}$ in $0.9 \% \mathrm{NaCl}$ aqueous solution. Cumulus-oocyte complexes (COCs) were aspirated from all visible follicles with an $18 \mathrm{G}$ needle, and pooled for maturation after selection.

\section{In vitro maturation (IVM)}

COCs were rapidly washed four times in HEPES buffered Tyrode's medium [46] supplemented with 0.3\% polyvinyl-pyrrolidone (PVP; Sigma), $0.25 \mathrm{mM}$ pyruvic acid (Sigma) and $50 \mu \mathrm{g} / \mathrm{ml}$ gentamycin (Sigma). After washing, 30-50 COCs were cultured in $1 \mathrm{ml}$ in vitro maturation (IVM)-medium [47], supplemented with $0.3 \% \mathrm{PVP}$, at $38.5 \mathrm{C}$ under an atmosphere of $5 \% \mathrm{CO}_{2}$ and $95 \%$ air with high humidity. After $24 \mathrm{~h}$ of maturation, COCs were used for vitrification. Before vitrification, some COCs were completely removed from cumulus cells by mechanically pipetting with a fine diameter pipette in TLH medium supplemented with 85 IU/ $\mathrm{ml}$ hyaluronidase.

\section{Vitrification solutions}

The solution used as a carrier for the cryoprotectants was Dulbecco's phosphate buffered saline (DPBS, without calcium chloride and magnesium chloride) supplemented with 1.0 $\mathrm{mg} / \mathrm{ml}$ glucose (Sigma), $0.11 \mathrm{mg} / \mathrm{ml}$ sodium pyruvate (Sigma), 20\% (v/v) fetal bovine serum and $0.05 \mu \mathrm{g} / \mathrm{ml}$ streptomycin. (1) The equilibration solution (ES) was prepared with either 7.5\% (v/v) ethylene glycol (EG; Sigma) $+7.5 \%$ (v/v) dimethylsulfoxide (DMSO; Sigma) or $7.5 \%(\mathrm{v} / \mathrm{v})$ $\mathrm{EG}+7.5 \%$ (v/v) 1,2-propanediol (PROH; Sigma) in DPBS; (2) The vitrification solution (VS) was prepared with either $15.0 \%(\mathrm{v} / \mathrm{v}) \mathrm{EG}+15 \%(\mathrm{v} / \mathrm{v})$ $\mathrm{DMSO}+0.5 \mathrm{M}$ sucrose (Sigma) or $15 \%(\mathrm{v} / \mathrm{v}) \mathrm{EG}+$ $15 \%$ (v/v) PROH + 0.5 M sucrose (Sigma) in DPBS; (3) The thawing solution (TS) was prepared with 1.0 M sucrose in DPBS; (4) The diluent solution (DS) was prepared with $0.5 \mathrm{M}$ sucrose in DPBS; (5) The washing solution (WS) used was basic DPBS.

\section{Vitrification and warming}

Oocytes with or without cumulus cells were suspended in ES at room temperature for $5 \mathrm{~min}$. Following equilibration, the oocytes were transferred to VS at room temperature for 45-60 seconds. The oocytes were then either loaded on Cryotop (Kitazato Ltd., Tokyo, Japan; Fig. 1) (2-5 oocytes) or a thin plastic sticker (30-50 oocytes; Fig. 2 ), and then immediately plunged into liquid nitrogen $\left(\mathrm{LN}_{2}\right)$ for storage (at least for 1 week). For warming, Cryotop or the thin plastic sticker were directly inserted into TS (37 C) for one minute. The warmed oocytes were transferred to DS for $3 \mathrm{~min}$, and then washed twice in WS for $5 \mathrm{~min}$. Oocyte survival was evaluated on the basis of the integrity

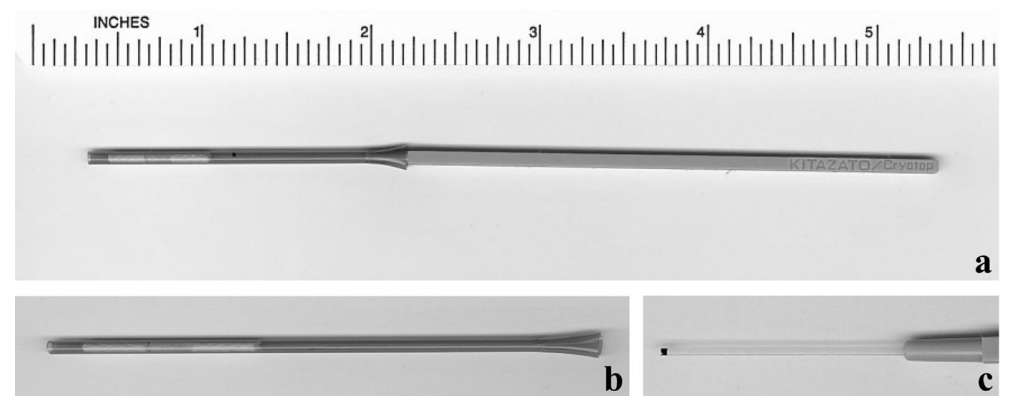

Fig. 1. A Cryotop (a) with cap (b) and loading portion (c). The loading portion is a thin polyethylene stick. 

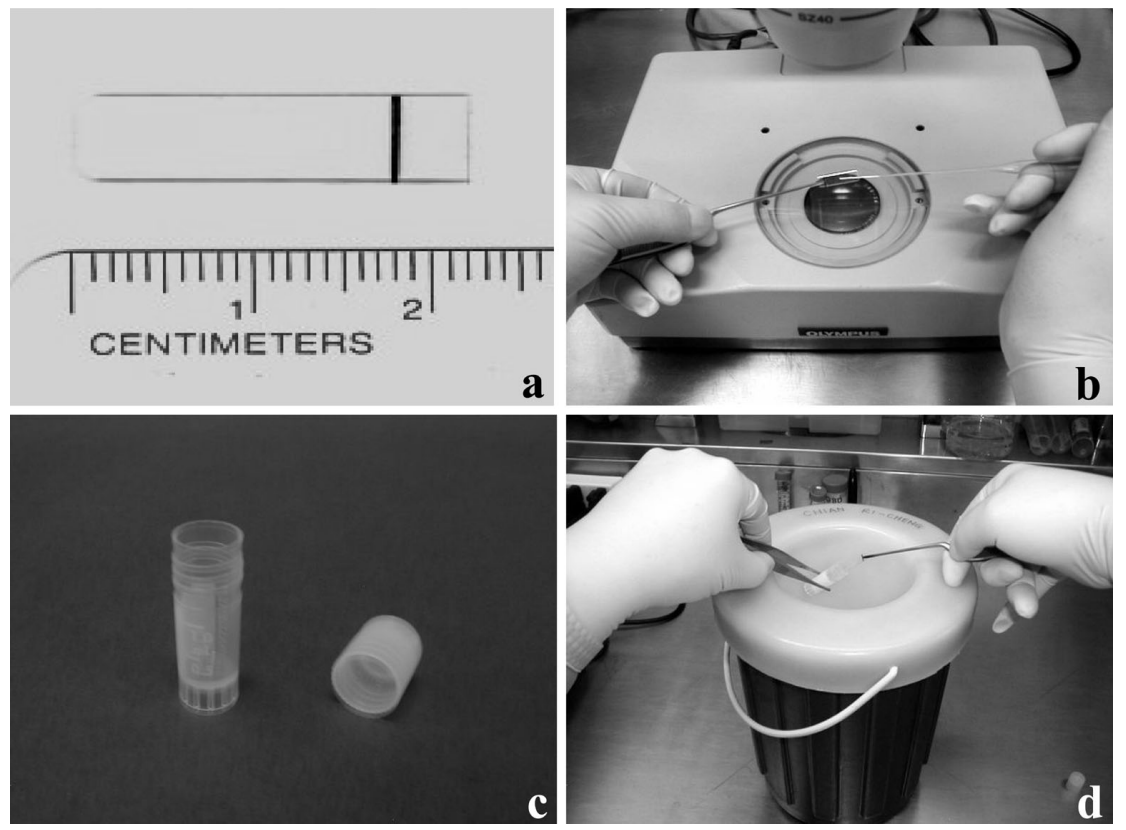

Fig. 2. A thin plastic sticker (a) $(20 \times 5 \times 0.2 \mathrm{~mm})$ being loaded with cumulus-oocytes complexes (COCs) under microscope (b), and the thin plastic sticker is inserted into a cryo-vial (c) for storage (d).

of the oocyte membrane and the zona pellucida after thawing 18-24 h of culture. The warming oocytes were subjected to in vitro fertilization (IVF) immediately. Some oocytes were completely denuded from cumulus cells by mechanically pipetting with fine diameter pipette before insemination.

\section{In vitro fertilization (IVF)}

Warmed bovine oocytes were inseminated with frozen-thawed semen pooled from five bulls donated by Centre d'Insemination Artificielle du Quebec (C.I.A.Q. Inc., St-Hyacinthe, Quebec). Straws of frozen semen were thawed in a water bath at $35 \mathrm{C}$ for 30 seconds and processed by swimup as described Parrish et al. [48]. The sperm were then washed twice in modified Tyrode's albumin lactate medium (Sp-TALP), used for sperm culture, which contained $6 \mathrm{mg} / \mathrm{ml}$ fatty acid-free BSA (Sigma), $10 \mathrm{mM}$ pyruvic acid, and $50 \mu \mathrm{g} / \mathrm{ml}$ gentamycin. Sperm/oocytes were incubated in 50 $\mu \mathrm{l}$ drops of the fertilization medium, modified Tyrode's medium (mTALP; [49]), containing $2 \mu \mathrm{g} /$ $\mathrm{ml}$ heparin (Sigma), under mineral oil at $38.5 \mathrm{C}$ in $5 \% \mathrm{CO}_{2}$ and $95 \%$ air with high humidity. A final sperm concentration of $1 \times 10^{6} \mathrm{sperm} / \mathrm{ml}$ was used for insemination and five oocytes were placed in each $50 \mu \mathrm{l}$ drop as described by Chian et al. [50].

\section{Embryo culture}

Following $18 \mathrm{~h}$ of insemination, 5-10 oocytes were transferred to $50 \mu \mathrm{l}$ droplets of development medium (BECM: Bovine Embryo Culture Medium [51]) supplemented with $3 \mathrm{mg} / \mathrm{ml} \mathrm{BSA} \mathrm{(Sigma)} \mathrm{and}$ $1 \mu \mathrm{g} / \mathrm{ml}$ gentamycin under mineral oil. The culture medium was changed at $48 \mathrm{~h}$ intervals until $120 \mathrm{~h}$ after insemination, and then the embryos (5 to 10) were transferred to $50 \mu \mathrm{l}$ droplets of BECM supplemented with $10 \%$ FBS and $0.25 \mathrm{mM}$ pyruvic acid (Sigma) for further developmental culture until day 8 (192 $\mathrm{h}$ after insemination).

\section{Experiment design}

Experiment 1: Effect of cryoprotectants: Following maturation in culture, the oocytes were completely denuded from cumulus cells as described above. The denuded oocytes were randomly divided into two treatment groups for vitrification: (1) the oocytes were vitrified with $15 \%$ (v/v) EG $+15 \%$ (v/ v) $\mathrm{PROH}+0.5 \mathrm{M}$ sucrose; (2) the oocytes were 
Table 1. Effects of ethylene glycol (EG) + 1,2-propanediol (PROH) or EG + dimethyl sulfoxide (DMSO) on survival rates of cumulus-free bovine oocytes vitrified using Cryotop (4 replicates).

\begin{tabular}{|c|c|c|c|c|c|c|}
\hline \multirow[b]{2}{*}{ Cryoprotectant ${ }^{*}$} & \multirow[b]{2}{*}{$\begin{array}{l}\text { No. of oocytes } \\
\text { examined }\end{array}$} & \multirow[b]{2}{*}{$\begin{array}{l}\% \text { oocytes } \\
\text { survived }^{* *}\end{array}$} & \multirow[b]{2}{*}{$\begin{array}{l}\% \text { oocytes } \\
\text { cleaved }^{* *}\end{array}$} & \multicolumn{3}{|c|}{$\%$ oocytes developed to ${ }^{* *}$ : } \\
\hline & & & & $\begin{array}{l}\text { 8-cell stage } \\
\text { (Day 3) }\end{array}$ & $\begin{array}{l}\text { Blastocyst } \\
\text { (Day 8) }\end{array}$ & $\begin{array}{l}\text { Expanded and hatched } \\
\text { blastocyst (Day 8) }\end{array}$ \\
\hline Control & 134 & $100.0 \pm 0.0^{\mathrm{a}}$ & $83.1 \pm 11.8^{\mathrm{a}}$ & $54.2 \pm 15.8^{\mathrm{a}}$ & $19.1 \pm 4.1^{\mathrm{a}}$ & $13.5 \pm 5.3^{\mathrm{a}}$ \\
\hline $\mathrm{EG}+\mathrm{PROH}$ & 135 & $97.6 \pm 4.2^{\mathrm{a}}$ & $69.8 \pm 9.3^{\mathrm{b}}$ & $44.8 \pm 10.2^{\mathrm{b}}$ & $7.4 \pm 4.1^{\mathrm{b}}$ & $3.2 \pm 2.1^{b}$ \\
\hline $\mathrm{EG}+\mathrm{DMSO}$ & 140 & $91.8 \pm 6.7^{\mathrm{a}}$ & $68.6 \pm 5.8^{\mathrm{b}}$ & $42.1 \pm 14.4^{\mathrm{b}}$ & $1.7 \pm 3.0^{c}$ & $0.9 \pm 1.5^{c}$ \\
\hline
\end{tabular}

${ }^{*}$ Control was fresh oocytes without vitrifying-warming; the final concentrations of EG, DMSO and PROH were $15 \%$ (v/v) respectively.

${ }^{* *}$ The percentages were based on the number of initial oocytes collected before vitrification.

${ }^{\mathrm{abc}}$ Indicate significant differences in the column $(\mathrm{P}<0.05)$.

vitrified with $15.0 \%$ (v/v) EG + 15\% (v/v) DMSO + $0.5 \mathrm{M}$ sucrose. The denuded oocytes (2-5 oocytes) were loaded onto Cryotop for vitrification. Following vitrifying-warming, the warmed oocytes were inseminated immediately with frozen semen. The survival rates of oocytes were compared among groups $18-24 \mathrm{~h}$ after insemination. As control, fresh COCs after $24 \mathrm{~h}$ maturation in culture were denuded from cumulus cells and used for IVF as described above. The fertilized zygotes were further cultured to assess the developmental ability.

Experiment 2: Effect of cumulus cells during vitrification: Following maturation in culture, COCs were randomly divided into two groups for vitrification: (1) oocytes with cumulus cells; (2) oocytes without cumulus cells. The oocytes were vitrified with $15 \%$ (v/v) EG + 15\% (v/v) PROH + $0.5 \mathrm{M}$ sucrose. The oocytes (2-5) were loaded onto Cryotop for vitrification. The survival rates were compared following vitrifying-warming. The warmed oocytes with cumulus cells were denuded completely from cumulus cells and then inseminated, and the cleaved embryos were further cultured for comparison of embryonic development. As control, fresh COCs after $24 \mathrm{~h}$ maturation in culture were denuded from cumulus cells and used for IVF as described above. The fertilization zygotes were further cultured to assess the developmental ability.

Experiment 3: Effect of pre-incubation time after thawing: COCs (30-50) were loaded onto the thin plastic sticker, which can hold more oocytes than Cryotop, and vitrified with 15\% (v/v) EG + 15\% $(\mathrm{v} / \mathrm{v}) \mathrm{PROH}+0.5 \mathrm{M}$ sucrose. Following vitrifying and warming, COCs were divided into 3 treatment groups for insemination: (1) insemination of the oocytes immediately after warming; (2) preincubation of the oocytes in fertilization medium for $2 \mathrm{~h}$ before insemination; (3) pre-incubation in fertilization medium for $4 \mathrm{~h}$ before insemination. As control, fresh COCs after $24 \mathrm{~h}$ maturation in culture were used for IVF as described above. Following IVF, the cleaved embryos were further cultured for comparison of embryonic development in each group.

\section{Statistical analysis}

Oocyte survival and embryo cleavage rates, as well as blastocyst formation rates, in each group were analyzed by one-way analyses of variance. When analyses revealed significance, the groups were compared using the Student-Newman-Keuls' test [52].

\section{Results}

\section{Experiment 1}

As shown in Table 1, the survival rates of bovine oocytes after warming were $97.6 \% \pm 4.2$ and $91.8 \%$ \pm 6.7 when the oocytes were vitrified with $15 \%$ (v/ v) $\mathrm{EG}+15 \%(\mathrm{v} / \mathrm{v}) \mathrm{PROH}+0.5 \mathrm{M}$ sucrose or with $15.0 \%(\mathrm{v} / \mathrm{v}) \mathrm{EG}+15 \%(\mathrm{v} / \mathrm{v}) \mathrm{DMSO}+0.5 \mathrm{M}$ sucrose, respectively. There were no differences compared to control $(100.0 \% \pm 0.0)$. Although the cleavage rates were not different between two treatment groups $(69.8 \% \pm 9.3$ vs. $68.6 \% \pm 5.8)$, they were significantly lower $(\mathrm{P}<0.05)$ compared to control $(83.1 \% \pm 11.8)$. The rates of embryo develop to the 8-cell stage was not different between the two treatment groups $(44.8 \% \pm 10.2$ vs. $42.1 \% \pm 14.4)$; 
Table 2. Survival rates of bovine oocytes with or without cumulus cells and their development post-fertilization following vitrification with EG + PROH using Cryotop (4 replicates)*

\begin{tabular}{|c|c|c|c|c|c|c|}
\hline \multirow{2}{*}{$\begin{array}{l}\text { Oocytes with }(+) \\
\text { or without }(-) \\
\text { cumulus cells }\end{array}$} & \multirow{2}{*}{$\begin{array}{c}\text { No. of oocytes } \\
\text { examined }\end{array}$} & \multirow[b]{2}{*}{$\begin{array}{l}\% \text { oocytes } \\
\text { survived }^{* *}\end{array}$} & \multirow[b]{2}{*}{$\begin{array}{l}\% \text { oocytes } \\
\text { cleaved }^{* *}\end{array}$} & \multicolumn{3}{|c|}{$\%$ oocytes developed to ${ }^{* *}$ : } \\
\hline & & & & $\begin{array}{l}\text { 8-cell stage } \\
\text { (Day 3) }\end{array}$ & $\begin{array}{l}\text { Blastocyst } \\
\text { (Day 8) }\end{array}$ & $\begin{array}{c}\text { Expanded and hatched } \\
\text { blastocyst (Day 8) }\end{array}$ \\
\hline Control & 150 & $100.0 \pm 0.0^{\mathrm{a}}$ & $77.6 \pm 6.4^{\mathrm{a}}$ & $66.3 \pm 15.4^{\mathrm{a}}$ & $17.5 \pm 15.2^{\mathrm{a}}$ & $11.4 \pm 10.6^{\mathrm{a}}$ \\
\hline+ & 129 & $84.0 \pm 1.0^{\mathrm{b}}$ & $67.1 \pm 7.3^{\mathrm{b}}$ & $29.3 \pm 3.2^{\mathrm{b}}$ & $6.9 \pm 1.2^{\mathrm{b}}$ & $2.9 \pm 1.2^{b}$ \\
\hline- & 140 & $92.8 \pm 5.2^{c}$ & $69.6 \pm 0.8^{b}$ & $37.0 \pm 6.0^{c}$ & $7.7 \pm 5.1^{\mathrm{b}}$ & $4.0 \pm 2.2^{b}$ \\
\hline
\end{tabular}

*Control was fresh oocytes without vitrifying-warming; the final concentrations of EG and PROH were $15 \%$ (v/v) respectively. **The percentages were based on the number of initial oocytes collected before vitrification.

${ }^{\mathrm{abc}}$ Indicate significant differences in the column $(\mathrm{P}<0.05)$.

Table 3. Effects of pre-incubation time after thawing on bovine embryonic development following vitrification with EG + PG using the thin plastic sticker (4 replicates)*

\begin{tabular}{lcccccc}
\hline $\begin{array}{l}\text { Time (h) of } \\
\text { pre-incubation }\end{array}$ & $\begin{array}{c}\text { No. of oocytes } \\
\text { examined }\end{array}$ & $\begin{array}{c}\text { \% oocytes } \\
\text { survived }\end{array}$ & $\begin{array}{c}\text { \% oocytes } \\
\text { cleaved }^{* *}\end{array}$ & $\begin{array}{c}\text { 8-cell stage } \\
\text { (Day 3) }\end{array}$ & $\begin{array}{c}\text { Blastocyst } \\
\text { (Day 8) }\end{array}$ & $\begin{array}{c}\text { Expanded and hatched } \\
\text { blastocyst (Day 8) }\end{array}$ \\
\hline Control & 161 & $100.0 \pm 0.0^{\mathrm{a}}$ & $79.6 \pm 7.1^{\mathrm{a}}$ & $60.2 \pm 12.5^{\mathrm{a}}$ & $27.5 \pm 9.1^{\mathrm{a}}$ & $24.6 \pm 9.8^{\mathrm{a}}$ \\
0 & 155 & $92.8 \pm 6.2^{\mathrm{ab}}$ & $71.9 \pm 2.8^{\mathrm{a}}$ & $35.7 \pm 7.2^{\mathrm{b}}$ & $7.9 \pm 5.1^{\mathrm{b}}$ & $4.1 \pm 2.0^{\mathrm{b}}$ \\
2 & 159 & $91.4 \pm 4.3^{\mathrm{ab}}$ & $70.1 \pm 8.3^{\mathrm{a}}$ & $30.1 \pm 5.6^{\mathrm{b}}$ & $5.9 \pm 6.2^{\mathrm{b}}$ & $2.4 \pm 1.7^{\mathrm{b}}$ \\
4 & 154 & $89.5 \pm 7.5^{\mathrm{b}}$ & $51.6 \pm 5.6^{\mathrm{b}}$ & $15.4 \pm 8.3^{\mathrm{c}}$ & $0.7 \pm 1.1^{\mathrm{c}}$ & $0.0 \pm 0.0^{\mathrm{c}}$ \\
\hline
\end{tabular}

*Control was fresh oocytes without vitrifying-warming; the final concentrations of EG and PROH were 15\% (v/v) respectively.

**The percentages were based on the number of initial oocytes collected before vitrification.

${ }^{\mathrm{abc} I n d i c a t e}$ significant difference in the column.

however, there were significant differences when compared to control $(54.2 \% \pm 15.8)$. The rates of embryos developing to the blastocyst stage $(7.4 \% \pm$ 4.1 vs. $1.7 \% \pm 3.0$ ) and reaching the expanded or hatched blastocyst stage $(3.2 \% \pm 2.1$ vs. $0.9 \% \pm 1.5)$ were also significantly different $(\mathrm{P}<0.05)$ between the two treatment groups, but they were significantly lower than those of control $(19.1 \% \pm$ 4.1 and $13.5 \% \pm 5.3$, respectively).

\section{Experiment 2}

As shown in Table 2, survival rates after thawing were significantly better $(\mathrm{P}<0.05)$ for bovine oocytes without cumulus cells $(92.8 \% \pm 5.2)$ as opposed to those with cumulus cells $(84.0 \% \pm 1.0)$ for vitrification using 15\% (v/v) EG $+15 \%(\mathrm{v} / \mathrm{v})$ $\mathrm{PROH}+0.5 \mathrm{M}$ sucrose. Although the cleavage rates were not different between these two treatment groups $(67.1 \% \pm 7.3$ and. $69.6 \% \pm 0.8$, respectively), they were significantly lower $(\mathrm{P}<0.05)$ than control $(77.6 \% \pm 6.4)$. The rates of embryos that developed to the 8-cell stage were significantly higher $(\mathrm{P}<0.05)$ in the oocytes without cumulus cells $(37.0 \pm 6.0)$ compared to with cumulus cells $(29.3 \% \pm 3.2)$. However, the rates of embryos developing to the blastocyst stage (6.9 \pm 1.2 vs. $7.7 \% \pm 5.1)$ or reaching expanded or hatched blastocyst stage $(2.9 \% \pm 1.2$ vs. $4.0 \% \pm 2.2)$ were not different between the two treatment groups, and they were significantly lower than those of control $(17.5 \% \pm 15.2$ and $11.4 \% \pm 10.6$, respectively).

\section{Experiment 3}

As shown in Table 3, although the survival rates of bovine oocytes after warming were not different among control, $0 \mathrm{~h}$, and $2 \mathrm{~h}$ of pre-incubation when the COCs were loaded on the thin plastic sticker Cryoleaf for vitrification with 15\% (v/v) EG + 15\% $(\mathrm{v} / \mathrm{v}) \mathrm{PROH}+0.5 \mathrm{M}$ sucrose, the results were different $(\mathrm{P}<0.05)$ between the $4 \mathrm{~h}$ pre-incubation $(89.5 \% \pm 7.5)$ and control $(100.0 \% \pm 0.0)$ groups. The cleavage rates were also significantly lower in the 4 $\mathrm{h}$ pre-incubation group $(51.6 \% \pm 5.6)$ when compared to the control group $(79.6 \% \pm 7.1)$ and the other two treatment groups $(71.9 \% \pm 2.8$ and $70.1 \%$ \pm 8.3 ), respectively. The rates of embryos 
developed to the 8-cell stage were not different between the $0 \mathrm{~h}$ and $2 \mathrm{~h}$ pre-incubation groups $(35.7 \% \pm 7.2$ vs. $30.1 \% \pm 5.6)$; however, there were significant differences $(\mathrm{P}<0.05)$ between these groups when compared to the $4 \mathrm{~h}$ pre-incubation group $(15.4 \% \pm 8.3)$. Furthermore, although the rates embryos developing to the blastocyst stage $(7.9 \% \pm 5.1$ vs. $5.9 \% \pm 6.2)$ or reaching the expanded or hatched blastocyst stage $(4.1 \% \pm 2.0$ vs. $2.4 \% \pm$ 1.7) were not different between the $0 \mathrm{~h}$ and $2 \mathrm{~h}$ preincubation groups, there were differences $(\mathrm{P}<0.05)$ between these groups when compared to the $4 \mathrm{~h}$ pre-incubation group $(0.7 \% \pm 1.1$ and $0.0 \% \pm 0.0)$. The rates of embryos developed to the 8-cell to expanded or hatched blastocyst stage in all the vitrified groups were significantly lower that those of control.

\section{Discussion}

The results of the present study demonstrate that bovine IVM oocytes can be vitrified successfully with the mixture of EG and $\mathrm{PROH}$, that the survival rates are higher for oocytes vitrified without cumulus cells, and that pre-incubation before insemination is not necessary for the vitrification of oocytes.

Permeating cryoprotectants, such as glycerol, DMSO and PROH, are often used to freeze oocytes and embryos in order to prevent intracellular ice crystal formation. For a slow freezing procedure, the concentrations of cryoprotectants are limited to 1 or $1.5 \mathrm{M}$, and the toxicity of cryoprotectants is relatively low. However, for vitrification, the concentrations of cryoprotectants used are much higher and, sometimes, can be as high as $8 \mathrm{M}$ [53]. Therefore, it seems more important to select cryoprotectants with low toxicity for the vitrification procedure. Both DMSO and $\mathrm{PROH}$ have higher membrane permeability than glycerol [52-54]. However, it has been reported that DMSO causes spindle polymerization in oocytes with increased potential for polyploidy [35, 56-59]. In addition, it has been known that the toxicity of DMSO for oocytes and embryos is related to the duration and temperature at which exposure occurs, indicating that oocytes in which are exposed to DMSO at lower temperatures have a better outcome [39, 60-61].

$\mathrm{PROH}$ is a less toxic and more permeable cryoprotectant when compared to DMSO [62-63]. It has been reported that there is no increase in the rates of aneuploidy or abnormal karyotype in onecell rabbit embryos [64] and mature mouse or human oocytes $[65,66]$ when they were treated with $\mathrm{PROH}$ as a cryoprotectant. However, $\mathrm{PROH}$ is not effective for cryopreservation of mouse and human oocytes when a slow freezing procedure is used because of a high incidence of parthenogenetic activation found after freezingthawing with $1.5 \mathrm{M}$ of PROH $[60,67,68]$. Nevertheless, Lim et al. [69] reported recently that $\mathrm{PROH}$ was the most effective, yielding greater success in embryonic development than either glycerol or DMSO in a slow freezing method combined with a rapid thawing protocol for bovine oocytes.

Another cryoprotectant, EG, has been widely used with both slow freezing and vitrification methods for cryopreservation of embryos and oocytes due to its low molecular weight, high permeation ability [70-73] and low toxicity [74, 75]. However, the use of EG alone seems to require higher concentrations of the cryoprotectant $(\geq 5.5$ M) [18]. Vitrification of bovine embryos was possible using a mixture of $16.5 \%$ EG and $16.5 \%$ DMSO and using a mixture of $20 \%$ EG and $20 \%$ DMSO as cryoprotectant [16]. These results indicate that the concentration of each cryoprotectant can be reduced if a mixture of cryoprotectants is used. The results of the present study support this hypothesis. Although the mixture of $15 \%$ EG and $15 \%$ DMSO is effective to vitrify human oocytes [13, 32] and embryos [30, 31], our result indicates that a mixture with a final concentration of $15 \% \mathrm{EG}$ and $15 \% \mathrm{PROH}$ is more efficient for oocyte vitrification than the mixture of 15\% EG and 15\% DMSO (Table 1). To the best of our knowledge, this is the first report that bovine oocytes can be vitrified successfully with the mixture of EG and PROH.

The beneficial effects of cumulus cells on oocyte survival rates after freezing-thawing have been reported when a slow freezing method was used [39, 40, 61]. However, a recent report does not support this finding [19]. Johnson and Pickering [39] have suggested that the presence of the cumulus cells can reduce the adverse effect of DMSO on the oocytes. It has also been suggested that the presence of cumulus cells can minimize the release of cortical granules and prevent premature 
zona reaction for zona hardening resulting in low fertilization rates [76, 77]. The results of the present study suggest that oocyte survival rates following vitrification are not affected by the presence or absence of cumulus cells. The fertilization rate also was not affected by the presence or absence of cumulus cells, indicating that there was no premature zona reaction for zona hardening occurred when the oocytes were vitrified without cumulus cells. In fact, the rates of embryos developed to the 8-cell stage in cumulus cell free group were significantly higher than that in cumulus cells intact group (Table 2). It has been mentioned that the oocytes partially denuded from cumulus cells before vitrification may be beneficial to subsequent fertilization and embryonic development [16]. However, there is no obvious explanation for this observation. It should be noted that the oocytes were easier to handle for vitrification using a Cryotop when the oocytes were denuded completely from their cumulus cells.

We have found that a maximum of 10-15 denuded oocytes can be loaded onto a Cryotop for vitrification, with an even smaller number if COCs are vitrified. Dinnyes et al. [78] reported that a large number of bovine oocytes can be vitrified if a metal surface is used, while Matsumoto et al. [79] reported that a larger quantity of bovine oocytes can be vitrified effectively using a nylon mesh than if an electronic microscope grid was used. In the present study, the thin plastic sticker allowed the loading of 30-50 COCs on the surface for vitrification. The results of the present study indicate that a large number of bovine oocytes with cumulus cells can be successfully vitrified using the thin plastic sticker with promising survival and cleavage rates reported here (Table 3 ). This suggests that the thin plastic sticker may be preferable for vitrification of a large number of oocytes.

It has been reported in murine [42] and bovine [43] oocytes that the abnormal appearance of the spindle following the slow freezing and rapid thawing returned to be normal after a period of incubation. It has been reported that, in the context of slow freezing, a pre-incubation of $2 \mathrm{~h}$ was required for the oocytes before insemination to improve the fertilizability and embryonic development of the freezing-thawed oocytes [41, 44, 45]. However, recently Saunders and Parks [80] found that even after $3 \mathrm{~h}$ of pre-incubation a normal spindle structure was not observed in bovine oocytes treated with slow freezing and rapid thawing. Results of the present study suggest that pre-incubation of the oocytes before insemination is not necessary for vitrified oocytes (Table 3). It is not clear why the rates of cleavage and embryonic development were lower when the oocytes were pre-incubated for $4 \mathrm{~h}$ compared to 0 and $2 \mathrm{~h}$ of preincubation. It is possible that a longer preincubation may lead to the release of cortical granules inducing zona-hardening. However, this would need to be further verified.

There are several advantages in using the bovine model to study the humans. They are similar in many ways including endocrine pathways, paracrine and autocrine pathways; reproductive cycling; the size of ovaries and oocytes; embryonic genome activation; the development of one preovulatory follicle during each cycle; and interaction with culture medium $[18,81]$. It is well known that bovine oocytes are more sensitive to the effects of chilling than other species' oocytes including the humans, because the cytoplasm of bovine oocytes contain many lipids [18]. Here we want to emphasize that our system for bovine oocytes of in vitro maturation (IVM) and in vitro culture (IVC) is different with other laboratories. We aspirate all visible follicles from bovine ovaries including the dominant follicle. The collected all COCs are subjected to IVM with serum-free IVM-medium [47]. Therefore, it is difficult to compare the final blastocyst formation rates based on initial number of COCs collected between laboratories. If based on the number of oocytes cleaved, the blastocyst formation rate routinely reaches to $40-50 \%$ in this IVM and IVC systems. In addition, it has been found that total cell numbers and ratio of inner cell mass (ICM)/trophectoderm (TE) in blastocysts were not different between control and treatments (data not shown). Based on the results of bovine oocyte vitrification, we have adapted this method of vitrification to human oocytes derived from in vitro maturation. Although the results for fertilization and embryonic development of human oocytes after vitrification were not available for the present, a $100 \%$ survival rate was observed for both immature and mature human oocytes following vitrification with a mixture of $15 \%$ EG and $15 \%$ PROH using a Cryotop (Data not shown). This further confirms that a high survival rate can be achieved from vitrified human oocytes using 
Cryotop [13], indicating that vitrification may be an efficient method for cryopreservation of human oocytes.

In conclusion, oocytes can be vitrified successfully with a mixture of cryoprotectants, EG + PROH. Better survival rates can be obtained when oocytes without cumulus cells are vitrified with a Cryotop. Pre-incubation of the oocytes before insemination is not necessary for vitrified oocytes. This vitrification method may be efficiently used for a program of human oocyte cryopreservation.

\section{Acknowledgments}

The authors thank Dr. Daniel Bousquet (L'Alliance Boviteq Inc.) and the Centre d'insemination artificielle du Quebec (CIAQ) Inc., and Mr. Tom Kroetsch (GENCOR, Guelph, Ontario) for providing the frozen bovine semen. Bovine ovaries were donated by Mr. Jean-Guy Dubé, Colbex Abattoir Inc., Drummond, Quebec. This research was partially supported by a grant from the Natural Sciences and Engineering Research Council (NSERC) of Canada (RGPIN 227107-00) to R. C. Chian.

\section{References}

1. Chen C. Pregnancy after human oocyte cryopreservation. Lancet 1986; I: 884-886.

2. Van Uem JF, Siebzehnrübl ER, Schuh B, Koch R, Trotnow S, Lang N. Birth after cryopreservation of unfertilized oocytes. Lancet 1987; I: 752-753.

3. Porcu E, Fabbri R, Seracchioli R, Ciotti PM, Magrini O, Flamigni C. Birth of a healthy female after intracytoplasmic sperm injection of cryopreserved human oocytes. Fertil Steril 1997; 68: 724-726.

4. Tucker MJ, Morton PC, Wright G, Sweitzer CC, Massey JB. Clinical application of human egg cryopreservation. Hum Reprod 1998; 13: 3156-3159.

5. Tucker MJ, Wright G, Morton PC, Massey JB. Birth after cryopreservation of immature oocytes with subsequent in vitro maturation. Fertil Steril 1998; 70: 578-579.

6. Young E, Kenny A, Piugdomenech E, Thillo GV, Tiveron M, Piazza A. Triplet pregnancy after intracytoplasmic sperm injection of cryopreserved oocytes: case report. Fertil Steril 1998; 70: 360-361.

7. Yang DS, Blohm PL, Winslow L, Cramer L. A twin pregnancy after microinjection of human cryopreserved oocyte with a specially developed oocyte cryopreservation regime. Fertil Steril 1998; 70 (Suppl. 1): S239.

8. Yang D, Winslow KL, Blohm PL, Brown SE, Nguyen K, Brubaker C. Oocyte donation using cryopreserved donor oocytes. Fertil Steril 2002; 78 (Suppl. 1): S14-S15.

9. Porcu E, Fabbri R, Ciotti PM, Marsella T, Balicchia B, Damiano B, Caracciolo D, Giunchi S, De Cesare R, Flamigni C. Cycles of human oocyte cryopreservation and intracytoplasmic sperm injection: results of 112 cycles. Fertil Steril 1999; 72 (Suppl.1): S2.

10. Kuleshova L, Gianaroli L, Magli C, Ferraretti A, Trounson A. Birth following vitrification of a small number of human oocytes. Hum Reprod 1999; 14: 3077-3079.

11. Yoon TK, Chung HM, Lim JM, Han SY, Ko JJ, Cha KY. Pregnancy and delivery of healthy infants developed from vitrified oocytes in a stimulated in vitro fertilization-embryo transfer program. Fertil Steril 2000; 74: 180-181.

12. Yoon TK, Kim TJ, Park SE, Hong SW, Ko JJ, Chung HM, Cha KY. Live births after vitrification of oocytes in a stimulated in vitro fertilization-embryo transfer program. Fertil Steril 2003; 79: 1323-1326.

13. Katayama KP, Stehlik J, Kuwayama M, Kato O, Stehlik E. High survival rate of vitrified human oocytes results in clinical pregnancy. Fertil Steril 2003; 80: 223-224.

14. Whittingham DG. Fertilization in vitro and development to term of unfertilized mouse oocytes previously stored at -196 C. J Reprod Fertil 1977; 49: 89-94.

15. Al-Hasani S, Kirsch J, Diedrich J, van der Ven H, Krebs D. Successful embryo transfer of cryopreserved and in-vitro fertilized rabbit oocytes. Hum Reprod 1989; 4: 77-79.

16. Vajta G, Holm P, Kuwayama M, Booth PJ, Jacobsen H, Greve T, Callesen H. Open pulled straw (OPS) vitrification: a new way to reduce cryoinjuries of bovine ova and embryos. Mol Reprod Dev 1998; 51: 53-58.

17. Parks JE, Ruffing NA. Factors affecting low temperature survival of mammalian oocytes. Theriogenology 1992; 37: 53-79.

18. Shaw JM, Oranratnachai A, Trounson AO. Fundamental cryobiology of mammalian oocytes and ovarian tissue. Theriogenology 2000; 53: 59-72.

19. Fabbri R, Porcu E, Marsella T, Rocchetta G, Venturoli S, Flamigni C. Human oocyte cryopreservation: new perspectives regarding oocyte survival. Hum Reprod 2001; 16: 411-416. 
20. Kuleshova LL, Lopata A. Vitrification can be more favorable than slow cooling. Fertil Steril 2002; 78: 449-454.

21. Rall WF, Fahy GM. Ice-free cryopreservation of mouse embryos at $-196 \mathrm{C}$ by vitrification. Nature 1985; 313: 573-575.

22. Martino A, Songsasen N, Leibo SP. Development into blastocysts of bovine oocytes cryopreserved by ultra-rapid cooling. Biol Reprod 1996; 54: 1059-1069.

23. Hong SW, Chung HM, Lim JM, Ko JJ, Yoon TK, Yee B, Cha KY. Improved human oocyte development after vitrification: a comparison of thawing methods. Fertil Steril 1999; 72: 142-146.

24. Choi DH, Chung HM, Lim JM, Ko JJ, Yoon TK, Cha KY. Pregnancy and delivery of healthy infants developed from vitrified blastocysts in an IVF-ET program. Fertil Steril 2000; 74: 838-844.

25. Chung HM, Hong SW, Lim JM, Lee SH, Cha WT, Ko JJ, Han SY, Choi DH, Cha KY. In vitro blastocyst formation of human oocytes obtained from unstimulated and stimulated cycles after vitrification at various maturational stages. Fertil Steril 2000; 73: 545-551.

26. Cho HJ, Son WY, Yoon SH, Lee SW, Lim JH. An improved protocol for dilution of cryoprotectants from vitrified human blastocysts. Hum Reprod 2002; 17: 2419-2422.

27. Son WY, Yoon SH, Yoon HJ, Lee SM, Lim JH. Pregnancy outcome following transfer of human blastocysts vitrified on electron microscopy grids after induced collapse of the blastocoele. Hum Reprod 2003; 18: 137-139.

28. Lane M, Schoolcraft WB, Gardner DK. Vitrification of mouse and human blastocysts using a novel cryoloop container-less technique. Fertil Steril 1999; 72: 1073-1078.

29. Yokoda Y, Sato S, Yokota M, Yokoda H, Araki Y. Birth of a healthy baby following vitrification of human blastocysts. Fertil Steril 2000; 75: 1027-1029.

30. Mukaida T, Nakamura S, Tomiyama T, Wada S, Kasai M, Takahashi K. Successful birth after transfer of vitrified human blastocysts with use of a cryoloop containerless technique. Fertil Steril 2001; 76: 618-620.

31. Mukaida T, Nakamura S, Tomiyama T, Wada $S$, Oka C, Kasai M, Takahashi K. Vitrification of human blastocysts using cryoloops: clinical outcome of 223 cycles. Hum Reprod 2003; 18: 384391.

32. Kuwayama M, Kato O. All-round vitrification method for human oocytes and embryos. J Assist Reprod Genet 2000; 17: 477.

33. Rall WF, Wood MJ, Kirby C, Whittingham DG. Development of mouse embryos cryopreserved by vitrification. J Reprod Fertil 1987; 80: 499-504.

34. Trounson A, Mohr L. Human pregnancy following cryopreservation, thawing and transfer of an eight- cell embryo. Nature 1983; 305: 707-709.

35. Glenister PH, Wood MJ, Kirby C, Whittingham DG. Incidence of chromosome anomalies in first cleavage mouse embryos obtained from frozen thawed oocytes fertilized in vitro. Gamete Res 1987; 16: 205-216.

36. Vanderzwalmen $\mathbf{P}$, Lejeune $B$, Zech $\mathbf{H}$, Nijs $\mathbf{M}$, Vandamme B, Prapas Y, Schoysman R. Pregnancy and implantation rates after transfers of fresh and vitrified embryos on day 4 or 5 . J Assis Reprod Genet 1999; 16: 147.

37. Vanderzwalmen $\mathbf{P}$, Bertin $\mathbf{G}$, Debauche $\mathbf{C H}$, Standaert V, van Roosendaal E, Vandervorst $M$, Bollen N, Zech H, Mukaida T, Takahashi K, Schoysman R. Birth after vitrification at morula and blastocyst stage: effect of artificial reduction of the blastocoeleic cavity before vitrification. Hum Reprod 2002; 17: 744-751.

38. Chi HJ, Koo JJ, Kim MY, Joo JY, Chang SS, Chung KS. Crtyopreservation of human embryos using ethylene glycol in controlled slow freezing. Hum Reprod 2002; 17: 2146-2151.

39. Johnson $\mathbf{M H}$, Pickering SJ. The effect of dimethylsulfoxide on the microtubular system of the mouse oocyte. Development 1987; 100: 313-324.

40. Imoedemhe DG, Sigue AB. Survival of human oocytes cryopreserved with or without the cumulus in 1,2-propanediol. J Assist Reprod Genet 1992; 9: 323327.

41. Im K, Kang JK, Kim HS. Effects of cumulus cells, different cryoprotectants, various maturation stages and preincubation before insemination on developmental capacity of frozen-thawed bovine oocytes. Theriogenology 1997; 47: 881-891.

42. Aigner S, Van der Elst J, Siebzehrubl E, Wildt L, Lang N, Van Steirteghem AC. The influence of slow and ultra-rapid freezing on the organization of the meiotic spindle of the mouse oocyte. Hum Reprod 1992; 7: 857-864.

43. Aman RR, Parks JE. Effects of cooling and rewarming on the meiotic spindle and chromosomes of in vitro-matured bovine oocytes. Biol Reprod 1994; 50: 103-110.

44. Lim JM, Fukui Y, Ono H. Developmental competence of bovine oocytes frozen at various maturation stages followed by in vitro maturation and fertilization. Theriogenology 1992; 37: 351-361.

45. Asada M, Fukui Y. Effect on fertilization and development by re-culture after freezing and thawing of bovine oocytes matured in vitro. Theriogeneology 2000; 54: 889-898.

46. Bavister BD, Leibfried LM, Lieberman G. Development of preimplantation embryos of the golden hamster in a defined culture medium. Biol Reprod 1983; 8: 235-247.

47. Chian RC, Tan SL. Maturational and developmental competence of immature human 
oocytes matured in vitro. Reprod BioMed 2002; 5: 125132.

48. Parrish JJ, Susko-Parrish JL, Leibfried-Rutledge ML, Critser ES, Eyestone WH, First NL. Bovine in vitro fertilization with frozen-thawed semen. Theriogenology 1986; 25: 591-600.

49. Parrish JJ, Susko-Parrish JL, Weiner MA, First NL. Capacitation of bovine sperm by heparin. Biol Reprod 1988; 38: 1171-1180.

50. Chian RC, Chung JT, Downey BR, Tan SL. Maturational and developmental competence of immature oocytes retrieved from bovine ovaries at different phases of folliculogenesis. Reprod BioMed 2002; 4: 129-134.

51. Lim JM, Okitsu K, Okuda K, Niwa K. Effects of fetal calf serum in culture medium on development of bovine oocytes matured and fertilized in vitro. Theriogenology 1994; 41: 1091-1098.

52. Steel RGD, Torrie JH. Principles and Procedures of Statistics: A Biometrical Approach. New York: McGraw-Hill Press, 1980: 172-194.

53. Kasai M. Advances in the cryopreservation of mammalian oocytes and embryos: development of ultrarapid vitrification. Reprod Med Biol 2002; 1: 1-9.

54. Mazur P. Cryobiology: the freezing of biological systems. Science 1970; 168: 939-949.

55. Fuku E, Kojima T, Shioya Y, Marcus GJ, Downey BR. In vitro fertilization and development of frozenthawed bovine oocytes. Cryobiology 1992; 29: 489492.

56. Al-Hasani S, Tolkdorf A, Diedrich K, van der Ven $\mathbf{H}, \mathbf{K r e b s} \mathbf{D}$. Successful in vitro fertilization of frozen thawed rabbit oocytes. Hum Reprod 1986; 1: 309-312.

57. Al-Hasani S, Diedrich $K$, van der Ven $\mathbf{H}$, Reinecke A, Hartje M, Krebs D. Cryopreservation of human oocytes. Hum Reprod 1987; 2: 695-700.

58. Kola I, Kirby C, Shaw J, Davey A, Trounson A. Vitrification of mouse oocytes results in aneuploidy zygotes and malformed fetuses. Teratology 1988; 38: 467-474.

59. Sathananthan AH, Trounson A, Freeman L, Brady T. The effect of cooling human oocytes. Hum Reprod 1988; 3: 968-977.

60. Van der Elst J, Van den Abbel E, Nerinckx S, Van Steirteghem A. Parthenogenetic activation pattern and microtubular organization of the mouse oocyte after exposure to 1,2-propanedior. Cryobiology 1992; 29: 549-562.

61. Trounson A, Kirby C. Problem in cryopreservation of unfertilized eggs by slow cooling in dimethyl sulfoxide. Fertil Steril 1989; 52: 778-786.

62. Boutron P, Kaufmann A. Stability of the amorphous state in the system water-1,2-propanedior. Crybiology 1979; 16: 557-568.

63. Renard JP, Babinet C. High survival of mouse embryos after rapid freezing and thawing inside plastic straws with 1,2-propanedior as cryoprotectants. J Exp Zool 1984; 230: 443-448.

64. Vincent C, Preliere G, Pajot-Augy E, Campion E, Garnier V, Renard JP. Effects of cryoprotectants on actin filaments during the cryopreservation of onecell rabbit embryos. Cryobiology 1990; 27: 9-23.

65. Gook DA, Osborn SM, Bourne H, Johnston WI. Fertilization of human oocytes following cryopreservation; normal karyotypes and absence of stray chromosome. Hum Reprod 1994; 9: 684-691.

66. Van Blerkom J, Davis PW. Cytogenic, cellular, and developmental consequences of cryopreservation of immature and mature mouse and human oocytes. Micro Res Tech 1994; 27: 165-193.

67. Shaw JM, Trounson AO. Parthenogenetic activation of unfertilized mouse oocytes by exposure to 1,2-propanedior is influenced by temperature, oocyte age, and cumulus removal. Gamete Res 1989; 24: 269-279.

68. Gook DA, Osborn SM, Johnson WI. Parthenogenetic activation of human oocyte following cryopreservation using $1.5 \mathrm{M}$ propanediol. Hum Reprod 1995; 10: 654-658.

69. Lim JM, Ko JJ, Hwang WS, Chung HM, Niwa K. Development of in vitro matured bovine oocytes after cryopreservation with different cryoprotectants. Theriogenology 1999; 51: 1303-1310.

70. Oda K, Gibbons WE, Leibo SP. Osmotic shock of fertilized mouse ova. J Reprod Fertil 1992; 95: 737747.

71. Gilmore JA, McGann LE, Liu J, Gao DY, Peter AT, Kleinhans FW, Critser JK. Effect of cryoprotectants solutes on water permeability of human spermatozoa. Biol Reprod 1995; 53: 985-995.

72. Zhu SE, Sakurai T, Edashige K, Machida T, Kasai M. Cryopreservation of zona-hatched mouse blastocysts. J Reprod Fertil 1996; 107: 37-42.

73. Newton H, Fisher J, Arnold JR, Pegg DE, Faddy MJ, Gosden RG. Permeation of human ovarian tissue with cryoprotective agents in preparation for cryopreservation. Hum Reprod 1998; 13: 376-380.

74. Sommerfeld V, Niemann H. Cryopreservation of bovine in vitro produced embryos using ethylene glycol in controlled freezing or vitrification. Cryobiology 1999; 38: 95-105.

75. Emiliani S, Bergh MVD, Vannin AS, Biramane J, Englert Y. Comparison of ethylene glycol, 1,2propanediol and glycerol for cryopreservation of slow-cooled mouse zygotes, 4-cell embryos and blastocysts. Hum Reprod 2000; 15: 905-910.

76. Vincent C, Pickering SJ, Johnson MH. The zona hardening effect of dimethyl sulfoxide requires the presence of an oocyte and is associated with reduction in the number of cortical granules present. J Reprod Fertil 1990; 89: 253-259.

77. Vincent C, Pickering SJ, Johnson MH, Quick SJ. Dimethyl sulfoxide affects the organization of microfilaments in the mouse oocyte. Mol Reprod Dev 
1990; 26: 227-235.

78. Dinnyes A, Dai Y, Jiang S, Yang X. High developmental rates of vitrified bovine oocytes following parthenogenetic activation, in vitro fertilization, and somatic cell nuclear transfer. Biol Reprod 2000; 63: 513-518.

79. Matsumoto H, Jiang JY, Tanaka T, Sasada H, Sato E. Vitrification of large quantities of immature bovine oocytes using nylon mesh. Cryobiology 2001;
42: 139-144.

80. Saunders KM, Parks JE. Effects of cryopreservation procedures on the cytology and fertilization rate of in vitro matured bovine oocytes. Biol Reprod 1999; 61: 178-187.

81. Speroff L, Glass RH, Kase NG. Clinical Gynecologic Endocrinology and Infertility. Lippincott Williams \& Wilkins: A Wolters Kluwer Company Press, 1999: 107-275. 